\title{
FROM THE IDEAL TO THE SPECTACULAR. HELLENIC ANTIQUITY AND THE DISCOURSE OF AUTHENTICITY
}

\section{DELIA TZORTZAKI}

\section{ABSTRACT/ABSTRAKT:}

In countries like Greece, where the material remains of the past play a predominant role in fostering a unifying national identity, the inspirational moment is antiquity. The aura of the authentic enlivens the discussion by fostering strong epistemological and political idioms vis-à-vis heritage applications.

The present article argues that the quest for authenticity in Hellenic heritage cuts through different styles, aesthetic approaches and technological means in order to put forth powerful stereotypes which can be traced both in speech and in exhibition contexts and affect the contemporary reception of material remnants. In this view, two generically distinct case-studies are discussed: The Parthenon marbles as presented in the speech of the then Minister of Culture, Antonios Samaras, at the Opening Ceremony of the New Acropolis Museum in 2009, and Digital Miletus, a by now classical virtual reality application featuring the reconstruction of the ancient city of Miletus, at the Foundation of the Hellenic World in Athens around the millennium. While the above examples seem initially opposing in terms of the kind of authenticity they invoke, they underline the same core notion, namely the identification of truths and values which travel, as in a time capsule, inside the ancient remnants. If heritage is to be critically assessed we need to move beyond the notion of finite contexts and unbreakable continuities and understand heritage representations more reflexively. We need to rethink both form and content because both carry argumentation and are not just objective, neutral means for entertainment and instruction.

\section{Od ideálního $\mathrm{k}$ velkolepému. Řecký starověk a problematika autenticity}

V zemích jako je Řecko, kde hmotné pozůstatky minulosti sehrávají klíčovou úlohu jednotícího činitele v budování národní identity, je hlavním inspiračním zdrojem období antiky. Fluidum autentičnosti oživuje diskusi podporováním hluboce zakořeněných gnozeologických a politických stereotypů tváří v tvář praktické ochraně kulturního dědictví. Autorka v článku uvádí, že při hledání autenticity starořeckých památek se uplatňují různé styly, estetické přístupy i technologie s cílem vytvářet silné a vlivné stereotypy, které je možné vysledovat jak ve veřejném mluveném projevu tak ve výstavnictví a které významnou měrou ovlivňují současné vnímání hmotného kulturního dědictví. Předmětem diskuse jsou v této souvislosti dvě případové studie o různých tématech: Parthenon marbles (Mramory z Parthenónu), prezentovaná v rámci proslovu bývalého ministra kultury Antonia Samarase při slavnostním otevření Nového muzea Akropole v roce 2009, a Digital Miletus (Digitální Milét), klasická virtuální aplikace zobrazující rekonstrukci starověkého města Milétu, prezentovaná na přelomu tisíciletí v athénské nadaci Foundation of the Hellenic World. Uvedené př́́klady se na první pohled zdají být ve vzájemném proti- kladu vzhledem k typu autenticity, na niž se odvolávají. Oba však sledují stejný cíl, a sice identifikaci skutečností a hodnot, jež jsou obsaženy ve starověkých památkách a cestují časem společně $s$ nimi. Pokud chceme přistupovat ke kulturnímu dědictví kritickým způsobem, musíme nahlížet za hranice neměnných souvislostí a neporušitelných kontinuit a vnímat projevy kulturního dědictví pružněji. Musíme přehodnotit jak jejich formu tak i obsah, protože obě tyto kategorie v sobě skrývají prvky argumentace a nejsou pouze objektivními, neutrálními prostředky sloužícími k zábavě a poučení.

\section{KEYWORDS/KLÍČOVÁ SLOVA:}

authenticity - ethnocentrism heritage - modern idealism - virtual reality - transparency - reflexivity autentičnost - etnocentrismus kulturní dědictví - novodobý idealismus - virtuální realita transparentnost - reflexivita

\section{Introduction ${ }^{1}$}

At a time when heritage is being blown up, manipulated for direct political causes, called "difficult" and judged according to peoples' values and expectations with an increasing intensity and persuasion, the cluster of knowledge called heritage studies has become the new progressive regime in cultural enquiry. Heritage studies

\footnotetext{
1 The present paper draws upon a lecture given at Masaryk University at Brno, Department of Archaeology and Museology, Centre of Museology, on May 18, 2016.
} 
(heritology, even) has gained momentum during the last decade by drawing upon established areas of knowledge such as museum studies, archaeology, history (also economic and cultural), social geography, architecture, visual cultural studies and other. ${ }^{2}$ Yet, the question of heritage as discourse, as a field of creating knowledge about past eras and about our own, is, I would argue, less rigorously researched.

In this paper I will explore the notion of the authentic in Hellenic heritage by juxtaposing two examples drawn from the horizon of the decade before and after the millennium. Those were times of national pride due to a general optimism of the 1990s reflected on the majestic opening ceremony of the Olympic Games in 2004. Five years later, and as the signs of the economic crisis were surfacing, the new Acropolis Museum was inaugurated bequeathing memorable rhetorical pieces praising the new museum. At the same time, critical accounts commenting on the ideological and epistemological impact of both the building and its layout and having mostly to do with our everlasting gaze towards antiquity appeared. ${ }^{3}$ For the

\footnotetext{
2 See for example the recent History and Approaches to Heritage Studies (Cultural Heritage Studies) edited by Messenger, F. M. and Bender, F. J. (2019) which summarises approaches in archaeological practice and education, also the ICOM publication Museums, Ethics and Cultural Heritage by Murphy, Bernice (2016) and Places of Pain and Shame: Dealing with 'Difficult Heritage' by Logan, W. (2009).

3 Dimitris Plantzos has critically reviewed the New Acropolis Museum along the same line (PLANTZOS, Dimitris. Behold the raking geison: the new Acropolis Museum and its context-free archaeologies. Antiquity, 2011, vol. 85, pp. 613630). I also refer the Greek reader to PLANTZOS, Dimitris. I Kivotos kai to Ethnos: ena sxolio gia tin ipodochi tou Neou Mouseiou Akropoleos [The Arc and the Nation. A comment on the reception of the new Acropolis Museum]. Sichrona Themata, 2009, vol. 106, pp. 14-18 and PLANTZOS, Dimitris. Il n'y a pas de hors-texte: to Mouseio tis Akropolis kai ta aponera tou idealismou [Il n'y pas de hors-texte: The Acropolis Museum in the wake of idealism]. Tetradia Mouseiologias, 2010, vol. 7, pp. 23-29. For the role of classical antiquity in
}

purpose of this article, the choice of the time frame synthesizes thoughts and approaches evident at the turn of the century, when the paradigm shifted towards phenomenological approaches on bodily experience, embodiment, synesthetic environments and emotive responses to learning. ${ }^{4}$ By juxtaposing two seemingly opposing case studies, the paper points to the way Hellenic heritage has been debated in the cultural sphere as a political tool par excellence, shaping belonging by virtue of its 'essentialist' attributes. By 'essentialist' I refer to a core of truth that needs to be unfolded, and linked to the present in a linear, straightforward manner. Much of the issues raised in the article refer to ongoing research ${ }^{5}$ focusing on the concept of authenticity, or else, the urge to reveal this core of truth either in words, i.e. in "millenialist rhetoric" 6 or, at the other end of the spectrum, in embodied historicism present in all sorts of immersive reconstructions and time-travelling applications.

\footnotetext{
the construction of the Modern Greek nation, see HAMILAKIS, Yannis. The Nation and its Ruins. Antiquity, Archaeology, and National Imagination in Greece. Oxford: Oxford University Press, 2009. For a detailed overview over the story of the Parthenon marbles and the logic of the new Acropolis Museum see LENDING, Mari. Negotiating absence. Bernard Tschumi's new Acropolis Museum in Athens. The Journal of Architecture [online]. 2009, September 4, pp. 567-589 [accessed 2019-11-22]. Available from www: <https://www.tandfonline. com/doi/pdf/10.1080/13602360903119363?needAccess $=$ true $>$.

4 The paradigm shift from the objective to the empathic is particularly discussed in HEIN, Hilde. The Museum in Transition. A philosophical perspective. Washington: Smithsonian University Press, 2000. See also page 14 of this article.

5 TZORTZAKI, Delia. Myth and the Ideal in 20th century Exhibitions of Classical Art. In TYLER, Jo Smith and Dimitris PLANTZOS. A Companion to Greek Art. Oxford: Blackwell Publishers, 2012, pp. 667-682; TZORTZAKI, Delia. The chronotopes of the Hellenic past. Virtuality, edutainment, ideology. In DAMASKOS, Dimitris and Dimitris PLANTZOS (eds.). A Singular Antiquity: Archaeology and Hellenic Identity in Twentieth-Century Greece. Athens: Benaki Museum, 2008, pp. 141-161.

6 PLANTZOS, Dimitris. Behold the raking geison: the new Acropolis Museum and its context-free archaeologies. Antiquity, 2011, vol. 85, p. 618.
}

The concept of authenticity is a powerful one. Why is authenticity haunting peoples' minds? What makes us think that quality and value intensify by the evocation of the original? Is it true that the effort to simulate the original works is an epistemological trap? Which kind of historiography does this suggest? Furthermore, the research has shown that authenticity is not a non-temporal phenomenon but rises when 18th-century reason, rationality and enlightenment break with pre-modern tradition and the omnipotence of God. At certain moments authenticity relates to beauty and harmony as transcendental ideals; at other times authenticity relates to science, research, data and accuracy. Those two main trends, which I term the Ideal and the Spectacular, will be touched upon in the following pages.

First, I will look at the authenticity of the original, using as an example the Parthenon marbles within the very specific context of Antonios Samaras', the then Minister of Culture, speech delivered at the Opening Ceremony of the New Acropolis Museum in 2009. ${ }^{7}$ The speech exemplifies the discourse of Classical antiquity put forth by Winckelmann in the 18 th century and is still alive and powerful in school texts, speeches, commemorations. ${ }^{8}$ It propagates austere beauty, argues for harmony and inner eternal truths and it is in fact a strong and telling example of how modern idealism, ever since the Enlightenment, has developed its rhetoric of purity vis-à-vis the

\footnotetext{
7 All excerpts from Samaras' speech are edited by Freya Evenson who also translated Samaras' speech (please see appendix).

8 For an analysis of ethnocentrism in Greek school texts and school education see (In Greek) FRAGOUDAKI, A. and T. DRAGONA. Ti ein i patrida mas? Ethnokentrismos stin ekpaidefsi [What is our country? Ethnocentrism in Education]. Alexandreia, 1997. The authors persuasively argue that Greek ethnocentrism is rooted upon the idea that (ancient) Greek values are timeless and have been handed down to us unchanged.
} 
past. The speech is set within the perfect context. Not only the marbles but also the architecture of the cement, minimalist building evoke the absence of the superfluous and the notion of the sublime. As Paul Greenhalgh persuasively argues, modern idealism has since the 18th-century solidified its major idioms, neoclassicism and 20th-century abstraction, thus bringing under the same 'white' roof the antique and the future. But this comes with a price. By alluring to the essence of things, modern idealism turns heritage into a non-temporal, free-floating visual effect.

Thus, the first part of the paper, the Ideal, draws upon Paul Greenhalgh's (2005) seminal book The Modern Ideal. The Rise and Collapse of Idealism in the Visual Arts. From the Enlightenment to Postmodernism in order to discuss the way romantic views on Greece have been informed by early modern protestant idealism and continue up to date. As mentioned before, this section sets itself within a broader context of critique at the time of the Museum's opening. In his acute comment titled "Behold the raking geison: the new Acropolis Museum and its context-free archaeologies" Plantzos writes: "The new Acropolis Museum, designed by Bernard Tsumi between 2001 and 2009) has to be seen [...] as a confirmation of Greece's dedication to modernity while at the same time promoting the timeless quality of its Classical Past." ${ }^{\prime \prime}$ After reviewing the national and international press's reaction upon the grand opening in June 2009, Plantzos argues that the Museum is expected to act as a unifying and inspirational element in Greek society, bearing as in the Arc of Moses, the testimonies of the eternal Greek

9 PLANTZOS, Dimitris. Behold the raking geison: the new Acropolis Museum and its context-free archaeologies. Antiquity, 2011, vol. 85, pp. 616-617. (or rather Hellenic) values which sustain the nationalist struggle. ${ }^{10}$ Hamilakis, on the other hand, commenting upon Plantzos 2011 pursues a slightly different line of critique by contextualising the marble masterpieces within the more universal debate of claim and ownership over heritage, engaging thus in a post-colonial argumentation that does not involve only the Hellenic classical past. Hamilakis' critique, albeit directed towards more global issues of heritage custodianship, relates strongly to Samaras' inaugural speech, which, clearly, was put together to argue for the return of the 'expatriated' marbles. Winckelmann's style is not accidentally or idiosyncratically chosen to be the language of cultural diplomacy in the speech. It is chosen because it creates strong vibrations both at a local and international level and this is the point I would like to make. ${ }^{11}$ To conclude, then, the Ideal is not tackling or criticising the new Acropolis Museum as a whole but understands the speech as a specimen of heritage rhetoric, which evokes evaluative commentary on contemporary Greece by comparison with the socalled Classical apex.

The second part, the Spectacular, moves from the purity of the original and its inherent metaphysical qualities towards its complete opposite. A virtual reality application of the ancient city of

\footnotetext{
10 PLANTZOS, Dimitris. I Kivotos kai to Ethnos: ena sxolio gia tin ipodochi tou Neou Mouseiou Akropoleos [The Arc and the Nation. A comment on the reception of the new Acropolis Museum]. Sichrona Themata, 2009, vol. 106, pp. 14-18. (In Greek)

11 It should also be noted that in his recent address (June 2019) to salute the first decade of the Museum's operation, the Director of the new Acropolis Museum Prof. D. Pantermalis, placed the emphasis on novelty and innovation, including new technologies and advanced communication strategies to amplify scientific knowledge and dissemination. President's message. In Acropolis Museum [online]. [accessed 2019-11-22]. Available from www: <https://www.theacropolismuseum. gr/en/content/organisation $>$.
}

Miletus in Asia Minor ${ }^{12}$ invokes stereotypical narratives about Greece as the cradle of civilisation, spreading over continents and seas. ${ }^{13}$ This is the argumentative line of the representation while its style makes claims to scientific technological research which enables us to visit the past "as it was". Life in antiquity is depicted by means of space reconstruction. Purity and simplicity are not the issue here. Authenticity is conjured by the accuracy of architectural features and mostly, bodily involvement, a techno-feature known as presence, in virtual reality terms. The more persuasive the photorealistic graphs are the more 'real' our experience with the digital environment becomes and the stronger the positivist stance that "truth is a copy". ${ }^{14}$ And this is an oxymoron, as such reconstructions borrow the tricks and tools from illusionary and make-believe spectacle in of virtual reality: "Everything that we know about our reality comes by way of our senses. In other words, our entire experience of reality is simply a combination of sensory information and our brains sense-making mechanisms for that information. It stands to reason then, that if you can present your senses with made-up information, your perception of reality would also change in response to it. You would be presented with a version of reality that isn' $t$ really there, but from your perspective it would be perceived as real. Something we would refer to as $a$ virtual reality [...]. Virtual reality is the term used to describe a three-dimensional, computer generated environment which can be explored and interacted with by a person. That person becomes part of this virtual world or is immersed within this environment and whilst there, is able to manipulate objects or perform a series of actions." What is Virtual Reality? In Virtual Reality Society [online]. [accessed 2019-11-11]. Available from www: < https://www.vrs.org.uk/virtual-reality/ what-is-virtual-reality.html $>$.

13 Digital Miletus is currently shown on a differ ent VR platform at the FHW, the Tholos (cupola), while the one discussed in this paper was shown on a CAVE platform (Computer Automatic Virtual Environment) where the visitor was wrapped within the three dimensional image in order to feel immersed and physically present by means of vision, hearing and kinaesthesia. A Walk Through Ancient Miletus. In Foundation of the Hellenic World [online]. [accessed 2019-11-22]. Available from www: <http://www.tholos254.gr/projects/ miletus/index-en.html>. See also note 26 .

14 HVIID JAKOBSEN, Michael. The Search for Sociological Truth. A History of the Rise and Fall of the Reign of Positivism in the Social Sciences. Sociology Working Paper, 1999, no. 1. 
order to turn history into images of restored ruins. Another important argumentative point of interactive technologies is the potentiality of 'choice' as opposed to predetermined decisions. Thus new media are flagged as novel pedagogical tools for constructivist, personalised learning able to create a total experience for the viewer/ participant.

In my analysis, I have recourse to Bolter and Grusin (1999) Remediation. Understanding new media. This seminal publication which only recently was translated into Greek and has become a core text in new media studies, draws the line between the previous century and new concerns coming up around the millennium. It is a time when theory strives to link modernity to postmodernity in order to prove that ruptures are just telling of the way historical thinking develops and do not define autonomous areas of knowledge production. Take for example minimalist abstraction in the 20th century. Minimalism seems fresh, cool and very modern while in reality it is connected to the moral and aesthetic simplicity of 15th-century Neoplatonism, cuts through the Baroque and reinstates itself in Enlightenment philosophy, literature and the arts, as I will discuss later.

\section{The ideal}

More than ten years ago, on June 20, 2009, a major event for Greece took place. The Acropolis Museum at Athens was inaugurated in a glamorous feast where prime ministers, princes and renowned personalities respectfully attended. At the opening ceremony Antonios Samaras, the then Minister of Culture delivered an impressive speech about the Parthenon marbles by way of re-introducing core notions of the neoclassical ideal.
Neoclassicism combines Platonic idealism revived in the Renaissance along with certain tendencies towards austerity and piety evident in religious (mainly Protestant) life. ${ }^{15}$ Those elements constitute the spine of the speech. It is actually striking how the choice of wording brings to mind ideas, such as simplicity, purity and essential beauty, put forth by enlightenment thinkers. Prominent among those thinkers is Johann Joachim Winckelmann, the Prussian historian and classicist of the 18th century, who spoke of the "high" and the "beautiful" in ancient Greek art, namely two facets/phases of the acclaimed 5 th century BC, the era of Pericles and Phidias. The high and the beautiful in Winckelmann's thinking constitute the apex of his classification system where rise and decline in ancient Greek art happen in the course of six centuries, from the Archaic to Hellenistic times. The high style identified with the work of Phidias contains an "elevated" expression "characterised by pure harmony and grandeur". ${ }^{16}$ It is in fact "the visible form of a Platonic form or idea, but locked in the irreducible contradiction of being simultaneously the image of a sensuous, beautiful figure and the embodiment of a pure idea [...] it represents the theoretical essence of the Greek ideal, but it is too rigorously pure to be imagined easily as an empirical phenomenon". ${ }^{17}$ The latter, i.e. the empirical aspect, is kept for the beautiful style identified with the work of Polykleitos. In contrast to high style, beautiful style is sensuous, more intimate, less law-like and austere.

\footnotetext{
15 GREENHALGH, Paul. The Modern Ideal. The Rise and Collapse of Idealism in the Visual Arts from the enlightenment to postmodernism. London: V\&A Publications, 2005, p. 150, 151.

16 POTTS, Alex. Flesh and the Ideal. Winckelmann and the origins of art history. New Haven: Yale University Press, 1994, p. 69. 17 Ibid.
}

Turning now to the speech, Samaras draws on the above by using both form and content so as to reflect modern idealism. In terms of form, the text uses words such as Harmony, Beauty, Virtue, Freedom, Reason, even beginning with a capital letter, as in the German language. In terms of content, Samaras describes the Parthenon marbles in a way reminiscent of the high and beautiful styles:

\section{[...] Even though you might be} visiting the Museum for the first time, I am sure you already feel at home. Because all that you see around you - in the halls of the Museum and across the way, on the Sacred Rock of the Acropolis symbolize ideas, principles values and ideals, which were born here, yet now belong to all of Humanity. On the Acropolis of Athens, all these ideals were immortalized as the substance of Harmony, that is the blending of Beauty and Reason, as the perfect complement to Virtue and Freedom.

\section{It [Parthenon] is a Monument to Beauty, which does not become complacent because it serves the Word of Harmony.}

It is a Monument to Freedom, which does not become overwhelming, because it serves Measure.

It is a Monument to man himself who does not become arrogant because he obeys the rules of Harmony.

According to Potts, Winckelmann's pursuit of freedom is not a quest for grand political values of the sort of the French Revolution but mostly a notion of the opening of consciousness, an internal freedom which is the basis for a righteous political system. The evocation of freedom in this frame traces, I would argue, a strong discourse of symmetry, balance, hence harmony in the private and political spheres, inspired and sustained by the 
aesthetic sphere of beauty in its abstract, pure form. Simplicity is a means for one to attain inner truths. It does not rely on intimacy but on a calm detachment. Not a paradox, thus, that enlightenment thinkers refer to simplicity as the highest virtue in art, critique, and politics alike. ${ }^{18}$

Further down in the speech, we read elliptic sentences, almost like aphorisms:

And they carved them of marble. And they dedicated them to the Goddess of Wisdom and protector of Athens. Inside a temple - the Parthenonwhich is both austere and elaborate. Which expresses Harmony. Which is the supreme Virtue, because it is equated with Beauty. And at the same time it is the utmost Freedom, because it is identified with Reason. Is it the deification of Man? Is it the humanization of the Divine? It is both! It is the apex [my emphasis] of the Hellenic Spirit, which through the Renaissance and the Enlightenment penetrated Western civilization. And today it constitutes the foundation of human civilization.

They are here, linking the development of the Hellenic spirit culminating in the Golden Age. The Archaic world paved the ground for this acme. And this unity, this continuity, this progression exists only here. The phenomenon of the Parthenon did not arise from thin air.

In the above quotations, Winckelmann's classification system bearing roots in the archaic world and culminating in the 5 th century BC, is clearly evoked. The whiteness of the sculpted marbles, though not explicitly stated, fits with the simplicity of

18 GREENHALGH, Paul. The Modern Ideal. The Rise and Collapse of Idealism in the Visual Arts from the enlightenment to postmodernism. London: V\&A Publications, 2005, p. 150. the building (i.e. the Parthenon). ${ }^{19}$ Even the word "apex" brings to mind Winckelmann's evaluation of the Parthenon period as the peak of his system. We must also note that the Parthenon marbles at the British Museum never entered the rigorous Darwinian classification but were excluded from the evolution chain, meaning that they were displayed in a room of their own, without forming part of any chronological or more systematic order. ${ }^{20}$ Authenticity in this case equates the birth and growth of civilization and as such, it does not need to be part of it. In a strange way, the same principle of being the apex of the display applies to the Acropolis Museum, where the Parthenon marbles are exhibited on the top floor of the Museum creating somehow a chronological conundrum with regard to the rest of the Acropolis monuments displayed elsewhere in the Museum.

Finally, it would seem important to refer to the platonic idea of the 'mind's eye' that lurks, as we have noticed before, throughout the text but only in the end becomes explicit. In other words, this is the idea that beauty is not a matter of pleasure deriving from contemplation but an inner truth revealed to the initiated:

Welcome to that which is ours and yours. Appreciate it. Enjoy it. Share it. Its contents and symbolisms have

19 Interestingly enough, the interior decoration of the Museum was executed by Adorno Urban Home, a Greek company known for its minimalism. An advertisement referring to the new Acropolis Museum mentions that the architecture and function of the Museum draws upon a simple and "clean" philosophy appealing to both the mind and the emotions of visitors. Further down, the text again brackets the words "simple life ideas"

in an attempt to fit to the general Museum concept of modern idealism. Adorno Urban Home [online]. [accessed 2019-11-22] < https://adorno.gr/index. php/el/projects-el-gr $>$.

20 TZORTZAKI, Delia. Myth and the Ideal in 20th century Exhibitions of Classical Art. In TYLER, Jo Smith and Dimitris PLANTZOS. A Com panion to Greek Art. Oxford: Blackwell Publishers, 2012, pp. 667-682. value only when they become the possession of all of mankind. They do not divide, but unite. They do not spread fanaticism, but spread light. They do not agitate for rebellion, but redeem. They do not impose, but liberate. You will not perceive this with your eyes alone; you will discover it in the depths of your soul. Because they bring to surface the deepest essence of human existence [my emphasis], which we all have hidden inside us, even if we often forget. It is all that we are, all that we feel, that makes us better and truer to ourselves. Ladies and Gentlemen, honourable guests, Welcome to the Acropolis Museum. Welcome home!

Another important element in the speech linking the Museum to a discourse of universalism (and an interesting form of confirming the existence of the so-called Universal Museums i.e. the British Museum, the Louvre and the like, now possibly including the Acropolis Museum in the pantheon), is the reference to humanity and the fact that cultural heritage is owned by each and every one of us.

To sum up, authenticity in the case of the Parthenon marbles is the boulder upon which humanity rests. Samaras' speech reproduces a well-known argumentation that draws upon, on the one hand, a universal enlightenment discourse on the eternal laws of harmony, and on the other hand, a national narrative appealing to the audiences by emphasizing excellence of past achievements and unbreakable continuity with the present. Authenticity at the Acropolis Museum has not much to do with the originals coming 'home' as opposed to the displayed casts. It is the symbolic, ideal presence of civilised mankind in the form of an utmost politicised and epistemologically traceable public performance. The Parthenon marbles and the Acropolis Museum 
in general bear the symbolic significance of the classical original as the birthmark of universal ideals.

I have singled out this speech in order to show how contemporary views on history, culture and society are flagged on the basis of material culture created thousands years ago. Furthermore, I would argue that Samaras' grandiose idealist style does not only deflect extra conservative minds but does indeed express the stereotype discourse purported in official and informal learning contexts. ${ }^{21}$ While the Acropolis Museum has shown signs of change because of the critique it has received over the years for its purist, decontextualised approach- (i.e. has revised the whiteness of the marbles and incorporated state of the art digital educational applications), this speech should in no way be interpreted as a personal view.

Let us now turn to the significance of authenticity when the original is absent.

\section{The Spectacular}

While copies were absolutely valid in Late Antiquity and made the ancient world known to the whole of Europe many centuries later, copies acquired the status of argument with the rise of national states. New technologies, apart from appealing to the need of visitors for edutainment, an early 20th-century concept of education and entertainment, ${ }^{22}$ serve the purpose of verification. The link between present and past was made possible via reconstructions of landscapes, houses, objects,

\section{See note 8.}

22 SPENCER, Hugh A. D. Supercharging the Cultural Engine: Advanced Media at Heritage and Educational Attractions. In DODSWORTH, Clark (ed.). Digital Illusion. New York: ACM Press/Addi son-Wesley Publishing, 1998, p. 491. monuments and most of all, events, in the form of historical re-enactments of battles, legends and daily life (i.e. Viking battles, the tales of King Arthur and other). The idea of capturing the past on the basis of time travelling, time machines and the like became utterly captivating for audiences and producers alike. Since the 1980s, the renowned Jorvik Center in the north of England, at the town of York, has been one of the forerunners of time travel, preaching the delights of a train ride going backwards, back to the 10th century $\mathrm{AD}$ and to the era of Vikings in England. ${ }^{23}$ The endeavour of experiencing past life as it was has been an everlasting human fantasy sought by 19th-century literature, film and all sorts of theme park machinery. However, the "invention of tradition" ${ }^{24}$ which legitimised claims to ancestry through a more or less unbroken timeline and therefore ascribed cultural heritage the status of a diplomatic weapon, constitutes the intellectual basis for the backward turn. ${ }^{25}$ Nation states attempted to construct a narrative of creation and survival through time, a phenomenon that took precedence after the French Revolution and gave rise to all sorts of heritage applications,

23 "These incredible discoveries enabled us to build JORVIK Viking Centre on the very site where the excavations had taken place, creating a groundbreaking visitor experience where you take a journey through the reconstruction of Viking-Age streets and experience life as it would have been in 10th century York." Read more at Jorvik Viking Centre [online]. [accessed 2019-07-14]. Available from www: <https://www.jorvikvikingcentre.co.uk/ about/\#CmjOhKhCxCKEt8bh.99">.

24 HOBSBAWM, Eric and Terence RANGER.

The invention of tradition. Cambridge: Cambridge University Press, 1983.

25 TZORTZAKI, Delia. The chronotopes of the Hellenic past. Virtuality, edutainment, ideology. In DAMASKOS, Dimitris and Dimitris PLANTZOS (eds.). A Singular Antiquity: Archaeology and Hellenic Identity in Twentieth-Century Greece. Athens: Benaki Museum, 2008, pp. 141-161 elaborating on Basil Bernstein's concept of retrospective pedagogical identiy, which fosters backward-looking nationalism: BERNSTEIN, Basil. Pedagogy, Symbolic Control and Identity. Theory, Research, Critique. Oxford: Rowman and Littlefield Publishers, 2000. tours, writings, mechanical and digital applications. The need to show the timeline in visual terms was strong and became even stronger with the help of new media. Eventually, a whole new market area within the broad spectrum of cultural heritage appeared and strengthened its position by setting foot in the research domain. University departments, conferences on digital cultural heritage, publications and a growing frenzy for more accurate and at the same time, more spectacular, reproductions have grown steadily during the last three decades.

To play the devil's advocate, digital heritage is not only about re-enacting the past. It is not only a staged performance, an instructive spectacle at best. It is also about interpretation, documentation, preservation and dissemination of valuable information vis-à-vis monuments of all kinds and in all sort of physical condition and/or danger. However, I would argue, the genealogy of illusion (western painting, camera technologies, dioramas, panoramas, theme park tradition) has made its mark on the field. As I will discuss below, heritage in its virtual form, reshapes illusion. The addition of virtuality, simulation, immersion and presence turns the viewer into a doer, which adds too much adrenaline to the experience. We will therefore examine some of the qualities apparent to virtual heritage, particularly virtual reality applications, which sustain and enhance the notion of authenticity.

\section{Digital Miletus, ${ }^{26}$ a classical example of virtual heritage}

26 A Walk Through Ancient Miletus. In Foundation of the Hellenic World [online]. [accessed 2019-11-22]. Available from www: <http://www. tholos254.gr/projects/miletus/index-en.html>. "At the Virtual Reality programme there is a tour at the meninsula [sic] and the city of Miletus, as it was 2,000 years ago. Visitors can explore the virtual city and learn about the most important public buildings. Starting from the gate at the Port of the Lions, they 
constructed in Greece, at the FHW, and shown there, in one of the three CAVEs that existed back then worldwide, was considered a vehicle of embodied truth. Maria Roussou, the main creator of Digital Miletus at the time of its triumphal innovative phase in the late 1990s, before virtual heritage had become a trendy topic in conferences around the world, had said: "Authenticity is both an effect that exhibit-makers strive to achieve and an experience that audiences come to expect from museums. It is thus crucial for museums to preserve this context of knowledge and credibility while providing memorable experiences that can tell the stories and ideally, suspend disbelief." 27

How, then, are such applications constituted?

Based on space and building reconstruction, virtual reality applications, which are non-static immersive representations, have been part of cultural heritage in its computerised form (digital cultural heritage) at least since the 1990s. Recently, at the 3rd International Congress and Expo New Realities: Authenticity and Automation in the Digital Age (San Francisco, 26-30 October 2018) ${ }^{28}$ there was a special session titled Emotions in Digital Cultural Heritage. It reminded

enter the sanctuary of Apollo Delphinios. Then, they visit the Ionian Stoa, which housed the stores of the city, the Hellenistic Gymnasium, the North Agora and the Bouleuterion, being able to see even the details of the buildings' architecture. They can 'fly' over the city for one last panoramic view of the perfect city planning design, or even 'dive' into its port."

27 ROUSSOU, Maria. The Interplay between Form, Story and History: The Use of Narrative in Cultural and Educational Virtual Reality. In BALET, Olivier, Gérard SUBSOL and Patrice TORGUET (eds.). Virtual Storytelling. Using Virtual Reality Technologies for Storytelling: International Conference on Virtual Storytelling 2001. Berlin, Heidelberg, New York: Springer-Verlag, 2001, p. 185.

28 Digital Heritage 2018 - 3rd International Congress \& Expo. In Digital Meets Culture [online] 8 March 2018 [accessed 2019-07-19]. Available from www: <https://www.digitalmeetsculture. net/article/digital-heritage-2018-3rd-international-congress-expo/>. me of a book published in 2000 titled the Museum in Transition. A Philosophical Perspective by the philosopher Hilde Hein, at a time when new media were worshipped as machines of human emancipation. Hein critically stressed the fact that museum experience, especially the part that involves human-

-machine interaction, is based on a counterpoint, namely a tension between the objective and the empathic, object accuracy and bodily experience. This has been vital in order to understand that objects and feelings are constitutive elements of instructive experiences appealing to mass audiences.

Authenticity is not only an intellectual concept but also an embodied situation, something that is happening rather than something we just think about or contemplate. As far as cultural heritage is concerned, authenticity is the claim to something true beyond the digital representation. It either lies in the objects that once stood there where now only ruins exist (object accuracy), or in the feelings that the visitors get when participating in the VR experience (multisensorial experience). Object accuracy is scientifically produced via measurement, calculation and algorithms. As I will discuss later, this line of thinking draws its credibility on positivistic notions of truth being a copy of something existing in the physical world. In terms of bodily experience, authenticity is produced via the invocation of the 'wow' effect, the spectacular part of the experience, the multisensorial participation in a synthetic environment that simulates the world out there.

Thus a peculiar kind of history arises, termed heritage history, which is both artefactual focusing on structures, items, human remains, and experiential focusing on the senses. Heritage history combines the aesthetics of realist illusion and its positivist epistemology with the aesthetics of embodiment and its phenomenological epistemology.

We can now investigate those constitutive elements more closely.

First, let us ponder over the tradition that lies behind object accuracy in virtual heritage. It is representational realism which rests on geometric, linear perspective. Representational realism favours the illusion of depth by giving the viewing pair of eyes the impression of walking through the image. This is the often cited "window to the world" metaphor attributed to the Renaissance painter Leon Battista Alberti and brings about a new conception of space: the geometric space of 15th-century Italian painting, which visualises Descartes' principles of mathematical space. ${ }^{29}$ While in antique and medieval times painted bodies and objects did not relate to each other within the space of depiction but remained individual shapes, with linear perspective space becomes coordinated by mathematical equations of height, width and depth. ${ }^{30}$

\section{With Comtean epistemology} dominating sociology and education since the 19th century, representational realism becomes a primary tool for communicating knowledge about the existing world. Sociological positivism as the "new epistemology of truth" 31 shares sides with the new "language of truth" brought about

29 For a thorough analysis of linear perspective and its epistemological implications see the classical work of JAY, Martin. Downcast eyes. The Denigration of Vision. Berkeley: University of California Press, 1994

30 For a clarification of the difference between classical subjective or curved perspective and Renaissance linear painting see PANOFSKY, Erwin. Perspective as Symbolic Form. New York: Zone Books, 1977.

31 HVIID JAKOBSEN, Michael. The Search for Sociological Truth. A History of the Rise and Fall 
with 19th-century camera technologies. ${ }^{32}$ A significant outcome is the genre of reconstructions, which establishes itself hegemonically in museums among other display modes and learning devices. Spanning from 19th-century museum models to contemporary virtual reality, reconstructions constitute an evolutionary line formed on the very same principle of objective representation. Echoing philosophers of the early 20th century such as Langer and early Wittgenstein, Hviid Jakobsen condenses the principle as follows: "Truth is a copy. Truth, in this view, exists when a statement reflects, as an immaculate picture, some kind of substance in the real world." ${ }^{33}$ Interestingly enough, Hviid Jacobsen claims that positivism, despite declarations of its death in the 1960s and 1970s, is far from being an obsolete enterprise but remains dominant in social theory. Taking up on this claim, I argue that contemporary virtual heritage (and heritage in general) renews the positivist ideal of modelling after nature. In his account of virtual archaeology as the reconstruction of archaeological "ecosystems", the acclaimed researcher Maurizio Forte puts forth a distinct form of techno-positivism. He argues that computer simulations reconstruct step-by-step an event by breaking it down to its primary elements via "reason" and "observation".

of the Reign of Positivism in the Social Sciences. Sociology Working Paper, 1999, no. 1, p. 6.

32 MCQUIRE, Scott. Visions of Modernity. Representation, Memory, Time and Space in the Age of the Camera. London: Sage Publications, 1998, p. 31 .

33 HVIID JAKOBSEN, Michael. The Search for Sociological Truth. A History of the Rise and Fall of the Reign of Positivism in the Social Sciences. Sociology Working Paper, 1999, no. 1, p. 39. See also TZORTZAKI, Delia. Plaisio, Morfi, Periehomeno. Politismiki proseggisi mias efarmogis eikonikis pragmatikotitas [Context, form, content. A cultural approach of a virtual reality application]. In Minutes of the 1st International Conference in Museology: Museology and New Media. University of the Aegean, Mytilini, 2004, pp. 51-63.
In Forte's own words, "synthetic images are intermediary beings between the world of ideas and the perceptible reality. They represent a 'non-reality' which exists, since they are the visualisation of the truth of the real". ${ }^{34}$ It is evident that tradition has left its mark on what we consider brand-new. Forte's last remark not only paints the picture of an ideal reconstruction but also brings to mind 18th-century efforts to create a universal language based on object observation, analysis and classification on the basis of taxonomic tables. ${ }^{35}$

Second, and most important, what are the implications of the truth as a copy principle when inscribed onto the body? In case of immersive virtual reality where the visitor/viewer is wrapped within the image with the help of stereoscopic glasses and various navigation tools, bodily symptoms such as nausea from moving too hastily or too clumsily might occur. The sense of depth, the notion, that is, of walking through the image, is thus enhanced by the actual physical reaction. One of the first producers of Digital Miletus in the CAVE of the FHW wrote back in the early days of the application: "[Immersion] offers a 'better than real life' or 'better than being there' experience." 36 In the case of immersive virtual heritage, human-computer interaction brings about or rather, re-invents, a particular connection between the body and the physical world. Phenomenological accounts emphasize the importance of corporeal presence in the mediated environment as an actual rupture

\footnotetext{
34 FORTE, Maurizio. About Virtual Archaeology. Disorders, Cognitive Interaction and Virtuality. In BARCELO, Juan A. (ed.) et al. Virtual Reality in Archaeology. Oxford: Archaeopress, 2000, p. 257.

35 See particularly FOUCAULT, Michel. Les mots et les choses. Paris: Gallimard, 1990.

36 Hellenic Cultural Heritage through Immersive Virtual Archaeology. In Proceedings of the 6th International Conference on Virtual Systems and Multimedia, Ogahi, Japan, 3-6 October 2000. 2000, p. 63.
}

with tradition. From the outset, it might look like a rupture, as this symbolic notion of not 'having' a body but of 'being' a body in the world becomes apparent. In cases where the purpose of the application is instructive, and the content adjusts to well-established narratives enhanced by magical tricks (flying carpets, flying over, diving into the image, witnessing the impossible), heritage history acquires strong argumentative connotations about how we can capture, tame and appropriate something which is only known, at best, from physical evidence. Bodily involvement corroborates the argument of time travel, time reversed, time captured. History becomes material heritage fully sensed, smelled, and almost touched. Social facts are dealt with "as if they were things" in line with Durkheim's physicalism, a particular version of positivism. ${ }^{37}$

This way, authenticity is no longer a mode of depicting things and places as visually close to the real as possible but acquires the experiential dimension of 'visiting them'. Despite the fact that in digital or synthetic realism there are elements which exceed the real and have been termed hyperreal (a shadow more intense than a real shadow, a colour more intense than a physical colour, a contrast more acute than in the physical world), the analogy between the computerised copies of buildings and landscapes and the ones which once stood there, as we know them from ancient sources, aims to retain the aura of the authentic. Positivism is still present, serving didactic purposes while disregarding epistemological implications.
37 HVIID JAKOBSEN, Michael. The Search for Sociological Truth. A History of the Rise and Fall of the Reign of Positivism in the Social Sciences. Sociology Working Paper, 1999, no. 1, p. 18. 
How exactly does Digital Miletus and all similar applications alike, do this? They do so by the principle of immediacy. Immediacy is crucial in the theory of remediation. ${ }^{38}$ It is the way to describe how photorealism and representational mimesis operate on the basis of the perspectival image. To enter the picture as 'a window to the world' needs the notion of transparency, the idea that the image is just a possibility of depth, a walk-in surface. The immediate effect of this notion is the strong sense that the medium is absent, erased. Even though new media preach active participation, they refashion ideas of early modernity, where the world stands as an objectively measurable entity outside of humans. Reason can tame experience. Hence, linear perspective solidifies representational realism as the aesthetic characteristic of the modern quest for transcendence. With photography, this is transformed into mechanics. Realism becomes "straight" instead of "expressionist", a fact which ascribes appearances the status of truth. ${ }^{39}$ Straight realism is owed to the credo that the fall of light emanating from the object onto the photographic film erases the human subject from the process and presents the depicted scene as it was. Erasure and automaticity are the formal principles of the photographic rhetoric. As the mechanical eye of reason, photography plays with uncontested truths marked by

38 See BOLTER, David Jay and Richard GRUSIN (eds.). Remediation. Understanding New Media. Cambridge, MA: The MIT Press, 1999. Remediation argues for the insertion of historical specificity into the study of new media. This means that new media draw upon previous and contemporary forms of visuality, spectacle and entertainmen with a very long trajectory in Western optical culture. No medium is created from scratch, argue the authors. Every medium 'remediates' its predecessors. This means that media carry epistemological and ideological weight, as with the case of photography.

39 MCQUIRE, Scott. Visions of Modernity. Rep resentation, Memory, Time and Space in the Age of the Camera. London: Sage Publications, 1998, p. 16 the 'naturally produced' presence of the real on the photographic surface. In spite of the fact that virtual applications, also virtual reality, are not photographs as such but digital drawings with no claims to naturalness whatsoever, photography has bequeathed its supposed mechanical objectivity. As Barthes in his early writings has argued, photography assists reality (and history for that matter) by amply ascribing the aesthetics of immediacy and transparency to the content. "Objective historical discourse" is then, the outcome of this process. ${ }^{40}$

To paraphrase Barthes and his classical dictum on photography, heritage history becomes the 'certificate of presence'.

If this is so, how can we create virtual heritage applications without having recourse to photorealistic, mimetic images? Would the idea of a digital drawing move our attention from transparency and immediacy and lay weight on hypermediacy, evident in the theory of remediation as the opposite principle of immediacy? From a knowledge theory perspective, this means to translate rather than quote; to create strange, past worlds rather than seamless interfaces; to evoke artificiality rather than the ideal copy. Instead of focusing on architecture and landscape reconstructions with or without humans and life in general, the designer could focus on the relation between past and present, what is possible to know and to reconstruct about the past and what is forever gone. Hypermediacy practises politics anew. Bearing upon the reflexivity of the digital drawing, the medium becomes visible (against immediacy) and some

40 BARTHES, Roland. The discourse of history. In SHAFFER, E. S. (ed.). Comparative Criticism: A Yearbook, vol. 3. Cambridge: Cambridge University Press, 1981 [1967], p. 11. space to think critically about contemporary heritage issues is created.

\section{Authenticity: A synthesis}

So far we have seen that authenticity can relate both to an idealised reality, as in the case of the antique marbles, and to science, research, data and accuracy, as in the case of Digital Miletus. There are common traits cutting through both cases, thus attesting to a common paradigm of authenticity, which has not been overtly challenged. Let me cite some of its main constituents:

\section{Historic time seems to be} passing without leaving any signs of change. In the case of the Parthenon marbles, the idealist rhetoric softens social and political change, i.e. change in mentalities, structures of society, institutional frames and human agents. It is as if the past can just be recaptured by the repatriation and unification of the marbles, or an accurate visual depiction, preferably immersive. Time is without temporality, as if the "in between" is not an issue.

2. While this observation may be more or less common in national narratives, namely in the way nations were constructed in the 19th century and sustained their ideological frame thereof, backward-looking in Hellenic heritage, is the norm. The fixation with the antique, either in physical or digital form, pins down heritage as a stereotyped and epistemologically narrow representation while avoiding questions about critical processes in knowledge production.

\section{This backward turn is} stylistically and philosophically substantiated by the principle of immediacy and transparency. The visual, be it an object of the Parthenon temple or a digitally 
reconstructed door in Miletus, is there for us to admire, with no filters of reflexivity to shadow its omnipotent message, namely that past and present are just points on the timeline accessed when proper technology, vision and political will intertwine.

As the last lines of this article were written, an international conference titled Embracing the virtual. European museums respond to the digital challenge was taking place at the new Acropolis Museum (December 21-22, 2019). One of the sessions, "Theoretical Perspectives, Authenticity and Representation" caught my immediate attention, only to realise that after decades of new media studies as an academic field we are still obsessed by "the aura of the exhibit" and the notion that the original artefacts "speak for themselves" as opposed to the manufactured digital objects, which definitely should not overshadow or outweigh the source. ${ }^{41}$ Digital Miletus was also present, as the background of today's more challenging and innovative immersive educational applications at the FHW. ${ }^{42}$ Yet, the scientific/ educational hope (and goal) still seemed to be the transcendence of historic time in order for Greek school kids and adults to revisit the past and be present at battles, and other historical highlights. On a more theoretical basis, Maria Roussou, who I have introduced earlier on in this paper, talked about the involvement of feelings in the reconstruction of archaeological sites, which as we have seen, has been a growing trend for at least thirty years now. She also talked about the value of

41 Paper presented by SHEHADE, M. and Th. STYLIANOU LAMBERT titled The digital transformation of museums: challenges and future directions, ICOM, European Conference 2019, 21. 11. 2019.

42 Paper presented by EFRAIMOGLOU, D. titled Virtual Reality and cutting edge technologies in Museums, 21. 11. 2019. personalised visits, and presented a digital application of extended reality at the new Acropolis Museum, in the Archaic Collection, where decorative elements, such as colouring, not visible to the naked eye, could be augmented and lead to more tailor-made narratives. ${ }^{43}$ However, throughout the conference the idea that the past is more than a photorealistic depiction, and that originals do not possess an aura unless we need them to, was not raised. ${ }^{44}$

To come full circle then, why is authenticity haunting peoples' minds? Is it, as Eco seems to argue, ${ }^{45}$ an atavistic quest, meaning that humans like to believe in the possibility of the true retrieval of things gone? The examination of the two case studies has shown that digital interfaces as well as physical objects, regardless of how acclaimed and deified they have become, are not transparent windows to the world but semiotic structures carrying cultural messages. Authenticity is yet again another discursive concept, exactly as reality is. In social sciences one does not enquiry what reality is but points out issues relating to how one understands and receives reality through media, literature, one's own senses even. Authenticity is constructed socially and as such, it needs analysis. The article concludes that reflexivity could set the limits to the quest for the authentic. It could familiarise us with the idea that both formal and informal learning processes (i.e. the official educational system as well as museums and other institutions of life-long learning)

\footnotetext{
43 ROUSSOU, Maria. Extending the virtual: the museum as a hybrid experience (keynote presentation, ICOM, European Conference 2019, 22. 11. 2019).

44 See also the seminal book The Past as a Foreign Country, a classical in museum studies teaching. LOWENTHAL, David. The Past as a Foreign Country. Cambridge: Cambridge University Press, 1999. 45 ECO, Umberto. Travels in Hyperreality. London: Pan Books, 1986.
}

ought to create learning subjects able to take a distance from the mirror effect and come to terms with their doings. This is probably the reason why Richard Sennett, ${ }^{46}$ commenting on man and his/her social comportment and obligations, elaborated on the risks of intimate society. Intimacy in late modernity renegotiates the 18th-century spectator by making the 'real' seem closer and graspable, thus strongly emotive. Instead of the hyper-reality of the 1980s and 1990s we are witnessing a hyper-authenticity haunted by the potentiality of a totally embodied reconstruction. Critical heritage, I would argue, demands that we set free from the epistemological trap of an idealised (past or present) reality. The gaps in grasping and depicting the past can become the fuel for new representation possibilities.

\section{APPENDIX 1: \\ Samaras' speech (translated into English by Freya Evenson)}

Even though you might be visiting the Museum for the first time, I am sure you already feel at home. Because all that you see around you - in the halls of the Museum and across the way, on the Sacred Rock of the Acropolis symbolize ideas, principles, values and ideals, which were born here, yet now belong to all of Humanity. On the Acropolis of Athens, all these ideals were immortalized as the substance of Harmony, that is the blending of Beauty and Reason, as the perfect complement to Virtue and Freedom.

And they remained standing throughout the centuries. To enlighten. To inspire. To support. To radiate. Art is a large weapon wielded by man to defeat the fear of death. And the manner with which each culture uses

\footnotetext{
46 SENNETT, Richard. The Fall of Public Man New York: W.W. Norton \& Company, 1974 (particularly chapters 5, 6, 9 and 14).
} 
Art shows its stance towards life and the precepts it leaves for eternity. They once made rigid forms. At another time they made schematic shapes. Later the creations took on a more human shape. And finally, in the Classical period, they became entirely human, with movement, expression, pathos.

And they carved them of marble. And they dedicated them to the Goddess of Wisdom and protector of Athens. Inside a Temple - the Parthenon - which is both austere and elaborate at the same time. Which expresses Harmony. Which is the supreme Virtue, because it is equated with Beauty. And at the same time it is the utmost Freedom, because it is identified with Reason. Is it the deification of Man? Is it the humanization of the Divine? It is both! It is the apex of the Hellenic Spirit, which through the Renaissance and the Enlightenment penetrated Western civilization. And today, it constitutes the foundation of human civilization. Ladies and Gentlemen, honourable guests, the marbles of the Acropolis are ours to share with the rest of the world. To share with you. That which they symbolize belongs to you, too.

- It [the Parthenon] is a Monument to Beauty, which does not become complacent because it serves the Word of Harmony.

- It is a Monument to Freedom, which does not become overwhelming because it serves Measure.

- It is a Monument to man himself, who does not become arrogant because he obeys the rules of Harmony.

These are the symbolisms of the Parthenon. And of the sculptures located here. Here in this space. And those that are not here, those that were broken-off and removed 207 years ago, they will return.

They must return.

The Parthenon and its sculptures fell victim to pillaging. Today this crime can be set right. The Museum is the moral power that calls them back. To be reunited. The marbles call the marbles! There is no room for petty politics here. We cannot negotiate the ownership of the marbles. We cannot negotiate our own dignity. We cannot legitimize their abduction two centuries ago. We cannot betray the integrity of the monument; we can only defend it, and restore it. We can sincerely cooperate with the British Museum. We can fill the resulting void with loans from Greece, mounting alternating exhibitions of outstanding examples of ancient Greek art.

We can discuss, we can agree. But the Parthenon marbles will be reunited here, in the Acropolis Museum! Because their reunification is a battle for the aesthetic integrity of the Monument, for the moral integrity of its symbolism. The Acropolis Museum is the symbol and catalyst of this global ethical judgement. And one more thing: This is not a Museum "deprived". Despite its wounds, it is a leading museum. Principal in the masterpieces of Classical art, and top in the artefacts from earlier periods! They are here, linking the development of the Hellenic spirit culminating in the Golden Age. The Archaic world paved the way for this acme. And this unity, this continuity, this progression exists only here. The phenomenon of the Parthenon did not arise from thin air.

The ideals symbolized here were born in the 6th century BC, with Solon's reforms and Kleisthenes' democracy. These were the precursors of the Golden Age.

Thus it is not just the unification that is missing - the unification of the marbles. The Museum gleams through the unity that exists within it and is projected for the first time. The unity of the ages. And it is this that makes it not just "wounded" but majestic despite its wounds. Majestic! And that is why today, the glorious Past of Greece addresses the Future of the World.
Ladies and Gentlemen, honourable guests, the Acropolis Museum is an "ark" of universal human and timeless Cultural Heritage.

Welcome to that which is ours and yours. Appreciate it. Enjoy it. Share it. Its contents and symbolisms have value only when they become the possession of all of mankind. They do not divide, but unite. They do not spread fanaticism, but spread light. They do not agitate for rebellion, but redeem. They do not impose, but liberate. You will not perceive this with your eyes alone; you will discover it in the depths of your soul. Because they bring to the surface the deepest essence of human existence, which we all have hidden inside us, even if we often forget. It is all that we are, all that we feel, that makes us better and truer to ourselves. Ladies and Gentlemen, honourable guests, Welcome to the Acropolis Museum. Welcome home!

\section{BIBLIOGRAPHY}

A Walk Through Ancient Miletus. In Foundation of the Hellenic World [online]. [accessed 2019-11-22]. Available from www: <http://www.tholos254.gr/projects/miletus/index-en.html $>$.

Adorno Urban Home [online]. [accessed 2019-11-22] < https://adorno.gr/index. php/el/projects-el-gr $>$.

BARTHES, Roland. The discourse of history. In SHAFFER, E. S. (ed.). Comparative Criticism: A Yearbook, vol. 3. Cambridge: Cambridge University Press, 1981 [1967], pp. 3-20. Translated with an introduction by Stephen Bann.

BERNSTEIN, Basil. Pedagogy, Symbolic Control and Identity. Theory, Research, Critique. Oxford: Rowman and Littlefield Publishers, 2000.

ISBN 978-0-8476-9576-8.

BOLTER, David Jay and Richard GRUSIN (eds.). Remediation. Understanding New Media. Cambridge, MA: The MIT Press, 1999. ISBN 978-0-262-26898-1.

Digital Heritage 2018 - 3rd International Congress \& Expo. In Digital Meets Culture [online]. 8 March 2018 [accessed 201907-19]. Available from www: <https:// 
www.digitalmeetsculture.net/article/ digital-heritage-2018-3rd-international-congress-expo/>.

ECO, Umberto. Travels in Hyperreality. London: Pan Books, 1986.

ISBN 978-0-330-29667-0.

FORTE, Maurizio. About Virtual Archaeology. Disorders, Cognitive Interaction and Virtuality. In BARCELO, Juan A. (ed.) et al. Virtual Reality in Archaeology. Oxford: Archaeopress, 2000, pp. 247-259. BAR International Series 843. ISBN 978-1-84171-047-1.

FOUCAULT, Michel. Les mots et les choses. Paris: Gallimard, 1990.

GREENHALGH, Paul. The Modern Ideal. The Rise and Collapse of Idealism in the Visual Arts from the enlightenment to postmodernism. London: V\&A Publications, 2005. ISBN 978-1-85177-469-2.

HAMILAKIS, Yannis. The Nation and its Ruins. Antiquity, Archaeology, and National Imagination in Greece. Oxford: Oxford University Press, 2009. ISBN 978-0-19-957290-8.

HEIN, Hilde. The Museum in Transition. A philosophical perspective. Washington: Smithsonian University Press, 2000. ISBN 978-1-56098-396-5.

Hellenic Cultural Heritage through Immersive Virtual Archaeology. In Proceedings of the 6th International Conference on Virtual Systems and Multimedia, Ogahi, Japan, 3-6 October 2000. 2000, pp. 57-64.

HOBSBAWM, Eric and Terence RANGER. The invention of tradition. Cambridge: Cambridge University Press, 1983. ISBN 978-0-521-24645-3.

HVIID JAKOBSEN, Michael. The Search for Sociological Truth. A History of the Rise and Fall of the Reign of Positivism in the Social Sciences. Sociology Working Paper, 1999, no. 1.

JAY, Martin. Downcast eyes. The Denigration of Vision. Berkeley: University of California Press, 1994.

ISBN 978-0-520-08885-6.

Jorvik Viking Centre [online]. [accessed 2019-07-14]. Available from www: $<$ https://www.jorvikvikingcentre.co.uk/ about/\#CmjOhKhCxCKEt8bh.99">.
LENDING, Mari. Negotiating absence. Bernard Tschumi's new Acropolis Museum in Athens. The Journal of Architecture [online]. 2009, September 4, pp. 567-589 [accessed 2019-11-22]. Available from www: <https://www.tandfonline.com/doi/ pdf/10.1080/13602360903119363?nee-

dAccess $=$ true $>$. https: $/ /$ doi. org/10.1080/13602360903119363

LOWENTHAL, David. The Past as a Foreign Country. Cambridge: Cambridge University Press, 1999. ISBN 978-0-521-29480-5.

MCQUIRE, Scott. Visions of Modernity. Representation, Memory, Time and Space in the Age of the Camera. London: Sage Publications, 1998. ISBN 978-0-7619-5301-2. PANOFSKY, Erwin. Perspective as Symbolic Form. New York: Zone Books, 1977.

PEARCE, Susan. Museums, Objects and Collections: A Cultural Study. Leicester: Leicester University Press, 1992. ISBN 978-0-7185-1442-6.

PLANTZOS, Dimitris. Behold the raking geison: the new Acropolis Museum and its context-free archaeologies. Antiquity, 2011, vol. 85, pp. 613-630.

PLANTZOS, Dimitris. I Kivotos kai to Ethnos: ena sxolio gia tin ipodochi tou Neou Mouseiou Akropoleos. Sichrona Themata, 2009, vol. 106, pp. 14-18.

PLANTZOS, Dimitris. Il n'y a pas de horstexte: to Mouseio tis Akropolis kai ta aponera tou idealismou. Tetradia Mouseiologias, 2010, vol. 7, pp. 23-29. ISSN 1790-0980.

PLANTZOS, Dimitris. Time and the Antique. Linear causality and the Greek art narrative. In DAMASKOS, Dimitris and Dimitris PLANTZOS (eds.). A Singular Antiquity. Archaeology and Hellenic Identity in Twentieth-Century Greece. Athens: Benaki Museum, 2008, pp. 253-272. ISBN 978-960-8347-96-0.

POTTS, Alex. Flesh and the Ideal. Winckelmann and the origins of art history. New Haven: Yale University Press, 1994. ISBN 978-0-300-05813-0.

President's message. In Acropolis Museum [online]. [accessed 2019-11-22]. Available from www: <https://www. theacropolismuseum.gr/en/content/organisation $>$.

ROUSSOU, Maria. The Interplay between Form, Story and History: The Use of Narrative in Cultural and Educational Virtual Reality. In BALET, Olivier, Gérard SUBSOL and Patrice TORGUET (eds.). Virtual Storytelling. Using Virtual Reality Technologies for Storytelling: International Conference on Virtual Storytelling 2001. Berlin, Heidelberg, New York: Springer-Verlag, 2001, pp. 181190. Lecture Notes in Computer Science, vol. 2197. ISBN 3-540-42611-6.

SENNETT, Richard. The Fall of Public Man. New York: W.W. Norton \& Company, 1974. ISBN 978-0-393-30879-2.

SPENCER, Hugh A. D. Supercharging the Cultural Engine: Advanced Media at Heritage and Educational Attractions. In DODSWORTH, Clark (ed.). Digital Illusion. New York: ACM Press/Addison-Wesley Publishing, 1998, pp. 489-500. ISBN 978-0-201-84780-2.

TZORTZAKI, Delia. Myth and the Ideal in 20th century Exhibitions of Classical Art. In TYLER, Jo Smith and Dimitris PLANTZOS. A Companion to Greek Art. Oxford: Blackwell Publishers, 2012, pp. 667-682. ISBN 978-1-4051-8604-9.

TZORTZAKI, Delia. Plaisio, Morfi, Periehomeno. Politismiki proseggisi mias efarmogis eikonikis pragmatikotitas. In Minutes of the 1st International Conference in Museology: Museology and New Media. University of the Aegean, Mytilini, 2004, pp. 51-63.

TZORTZAKI, Delia. The chronotopes of the Hellenic past. Virtuality, edutainment, ideology. In DAMASKOS, Dimitris and Dimitris PLANTZOS (eds.). A Singular Antiquity: Archaeology and Hellenic Identity in Twentieth-Century Greece. Athens: Benaki Museum, 2008, pp. 141-161. ISBN 978-960-8347-96-0.

What is Virtual Reality? In Virtual Reality Society [online]. [accessed 2019-11-11]. Available from www: < https://www.vrs. org.uk/virtual-reality/what-is-virtual-reality.html>. 


\section{DELIA TZORTZAKI}

University of Bergen - Norwegian Institute at Athens, Athens, Greece delia.tzortzaki@uib.no

Delia Tzortzaki is a University of Bergen - Norwegian Institute at Athens (NIA) staff member, working as Higher Executive Officer in Finances and Culture. She holds a PhD. in Museology, 2007, Roskilde University, Denmark and an MA in Gallery Studies, 1992, University of Essex, UK. At NIA she pursues her professional interests in the field of exhibition and conference organizing, and she is currently the main editor of the collective volume The Theory of Museology. Main Schools of Thought 1960-2000. For the last three decades she is active in teaching and researching Museology

(undergraduate and postgraduate university courses in Greece and abroad) and since 2009 the Athens School of Fine Arts has been her lecturing environment (Museology and Curation Studies). She has also worked in museums, cultural bodies and the Hellenic Ministry of Culture and Sports (resigned in 2018). Her research interests focus on the theory and history of museums and museology, the study of digital cultural heritage within the sphere of edutainment, the theory of collections as well as the history and process of curating. An ICOM member since 1992.
Delia Tzortzaki je zaměstnaná

v Norském institutu v Athénách (NIA), spravovaném Univerzitou v Bergenu, jako vedoucí pracovnice pro finance a kulturu. Doktorské studium (PhD.) v oboru muzeologie absolvovala $v$ roce 2007 na univerzitě v dánském Roskilde a magisterský titul v oboru galeristika získala $\mathrm{v}$ roce 1992 na univerzitě v Essexu ve Velké Británii. V rámci NIA se zabývá organizováním výstav a odborných konferencí a v současnosti je hlavní editorkou sborníku The Theory of Museology: Main Schools of Thought 19602000 (Teorie muzeologie: hlavní myšlenkové proudy v období let 1960-2000). Poslední tři desetiletí se aktivně věnuje pedagogické a výzkumné činnosti v oboru muzeologie (všechny stupně univerzitního studia v Recku i zahraničí) a od roku 2009 přednáší rovněž na Akademii výtvarného umění v Athénách (Muzeologie a Památková péče). Pracovala také v muzeích, kulturních institucích a na řeckém Ministerstvu kultury a sportu (do roku 2018). Ve své odborné práci se zaměřuje na teorii a dějiny muzeí a muzeologie, studium digitálního kulturního dědictví v oblasti edutainmentu, teorii sbírek a dějiny a proces památkové péče. Od roku 1992 je členkou ICOM. 